Acta Bot. Croat. 73 (1), 51-62, 2014

\title{
Salt stress tolerance in cowpea is poorly related to the ability to cope with oxidative stress
}

\author{
Sidney C. Praxedes ${ }^{1}$, Fábio M. Damatta ${ }^{2}$, Claudivan F. de Lacerda ${ }^{3}$, José T. \\ PRISCO $^{4}$, ENÉAS GOMES-FILHO ${ }^{4 *}$ \\ ${ }^{1}$ Unidade Acadêmica Especializada em Ciências Agrárias, Universidade Federal do Rio \\ Grande do Norte, RN 160, km 03, Distrito de Jundiaí, 59280-000 Macaíba-RN, Brazil \\ 2 Departamento de Biologia Vegetal, Universidade Federal de Viçosa, 36571-000 Viçosa, \\ Minas Gerais, Brazil \\ ${ }^{3}$ Departamento de Engenharia Agrícola, Universidade Federal do Ceará, 60455-760 \\ Fortaleza, Ceará, Brazil \\ ${ }^{4}$ Departamento de Bioquímica e Biologia Molecular and Instituto Nacional de Ciência e \\ Tecnologia em Salinidade (INCTSal/CNPq), Universidade Federal do Ceará, Caixa \\ Postal 6039, 60440-970 Fortaleza, Ceará, Brazil
}

\begin{abstract}
We have previously demonstrated that salt tolerance in cowpea could be associated with lesser impairments of the photosynthetic capacity. Taking into account that photosynthesis is the main sink for reducing power consumption, our central working hypothesis is that a salt-sensitive cultivar is more prone to suffer from oxidative stress. We analyzed the long-term effects of salt stress on oxidative damage and protection against reactive oxygen species in both leaves and roots of a salt-tolerant (Pitiúba) and a salt-sensitive (TVu) cowpea cultivar. Two salt treatments $(0$ and $75 \mathrm{mM} \mathrm{NaCl})$ were applied to 10-day-old plants grown in nutrient solution for 24 days. Significant salt-induced oxidative damage as demonstrated via increases in malondialdehyde concentration were noted, particularly in leaves at the end of the experiment, although such damage was found earlier in Pitiúba. In salt-stressed plants, superoxide dismutase (SOD) activity increased only in Pitiúba at 24 days from the start of salt additions (DSSA). In Pitiúba, catalase (CAT) was not significantly affected by the treatments, whereas in TVu its activity was dramatically lower in salt-stressed plants at 10 DSSA onwards. In general salt stress led to significant increases, much more pronounced in ascorbate peroxidase (APX), glutathione reductase (GR) and guaiacol peroxidase (GPX), at the end of the experiment in both cultivars. In roots, salt-induced increases in enzyme activities were particularly noted at 24 DSSA, as found for SOD and APX in Pitiúba, CAT in TVu and GR and GPX in both cultivars. Therefore, in contrast to our expectations, the present results argue, to a great extent, against a functional link between salt stress tolerance and the expression of the antioxidant system.
\end{abstract}

* Corresponding author, e-mail: egomesf@ufc.br

Copyright $^{\circledR} 2014$ by Acta Botanica Croatica, the Faculty of Science, University of Zagreb. All rights reserved. 
Praxedes S. C., Damatta F. M., De Lacerda C. F., Prisco J. T., Gomes-Filho E.

We also demonstrated that leaves and roots should be evaluated for a full assessment of whole plant acclimation to salt stress.

Key words: Antioxidative defense, oxidative stress, salt tolerance, Vigna unguiculata

Non-standard abbreviations: APX - ascorbate peroxidase; CAT - catalase; DSSA days from the start of salt additions; GPX - guaiacol-type peroxidase; GR - glutathione reductase; MDA - malondialdehyde; ROS - reactive oxygen species; SOD - superoxide dismutases

\section{Introduction}

Soil salinity is a major threat to global food security. Up to $20 \%$ of the world's irrigated land, which produces one third of the world's food, is salt-affected. Tolerance to salt stress is a complex trait involving the coordinated action of many gene families that perform a variety of functions such as control of water loss through stomata, ion sequestration, metabolic adjustments, osmotic adjustments and antioxidative defense (ABOGADALLAH 2010). In fact, salt-induced alterations in the physiology of the plants may provoke metabolic disturbances that trigger an excessive production of reactive oxygen species (ROS) (HASEGAWA et al. 2000, AHMAD et al. 2008). To cope with ROS, plants are endowed with a complex nonenzymatic and enzymatic antioxidant system including superoxide dismutases (SOD), which catalyze the reaction from superoxide to $\mathrm{H}_{2} \mathrm{O}_{2}$, and catalase (CAT) and enzymes of the ascorbate/glutathione cycle, including ascorbate peroxidase (APX) and glutathione reductase (GR), which function to detoxify the $\mathrm{H}_{2} \mathrm{O}_{2}$ produced (AsAdA 1999, MitTler 2002). Eventually, a guaiacol-type peroxidase (GPX) also participates in $\mathrm{H}_{2} \mathrm{O}_{2}$ scavenging (ZHANG and KIRKHAM 1996). Failure of the antioxidant defense system may result in oxidative damage to several cell constituents such as proteins, enzymes, DNA and membrane lipids (AsAda 1999, MitTler 2002).

In spite of the large number of reports on the role of antioxidative defense under salt stress, the relative importance of the antioxidant system to the overall plant salt tolerance is still a contentious matter (PARIDA and DAs 2005, MunNS and TeSTER 2008, AbOGADAllah 2010). On the one hand, the enzymatic ability to scavenge ROS is assumed to be an essential component of salt tolerance, based on studies on mutant and transgenic plants with greater capacities to detoxify ROS that showed improved salt tolerance (HASEGAWA et al. 2000, PARIDA and DAS 2005). On the other hand, it has been suggested that genetic differences in salt tolerance are not necessarily due to differences in the enzymatic ability to scavenge ROS (MUNNS and TESTER 2008) probably because the defense mechanisms pathways are redundant (PALATniK et al. 2002, MunNs and TeSTER 2008).

Cowpea is one of world's most important crops (EHLERS and HALL 1997) that are grown mostly in regions prone to salt stress. However, this species is as yet genetically underexploited (TIMKO et al. 2008). Little information on the basic processes involved in salt stress tolerance in cowpea is available. To the best of our knowledge, only two studies have explored the cowpea's antioxidative responses to salt stress, either by analyzing only leaves (MAIA et al. 2010) or both leaves and roots (CAVALCANTI et al. 2007), though limited to short-term evaluations without consideration of the duration of exposure of the plants to salt stress. We believe that studies involving both leaves and roots are important for a better understanding of the long-term physiological performance of the whole plant under salt stress conditions. 
Recently, we demonstrated that salt tolerance in cowpea was associated with restricted $\mathrm{Na}^{+}$accumulation in leaves, improved leaf area and lesser impairments of the photosynthetic capacity (PRAXEDES et al. 2010). Because photosynthesis is the main sink for reducing power consumption, our central working hypothesis is that a salt-sensitive cultivar is more prone to suffer from oxidative stress that, in turn, will probably aggravate its susceptibility to salt stress. We also hypothesized that leaves and roots display different antioxidative abilities to cope with salt stress. Therefore, the present study was conducted to analyze the long-term effects of salt stress in both leaves and roots of two cowpea cultivars with contrasting tolerance to salt stress.

\section{Material and methods}

\section{Plant material and growth conditions}

Two cowpea [Vigna unguiculata (L.) Walp] cultivars displaying varying tolerance to salt stress were used: Pitiúba (salt-tolerant) and TVu 2331 (salt-sensitive). These cultivars have been selected according to their growth responses to salinity, i.e., the tolerant cultivar displays less impaired growth and photosynthesis under salt conditions than does its sensitive counterpart (COSTA et al. 2003, PRAXEDES et al. 2010). Seeds were surface-sterilized in 1\% sodium hypochlorite for $5 \mathrm{~min}$, followed by rinsing three times in distilled water, after which they were sown in vermiculite moistened with distilled water. Five days after sowing, uniform seedlings were transplanted into trays containing half-strength Hoagland's nutrient solution, and acclimated for 5 days. Then, seedlings of each cultivar were transferred to $3-\mathrm{L}$ pots containing the same nutrient solution and randomly subjected to two salt treatments: 0 (control) and $75 \mathrm{mM} \mathrm{NaCl}$. Salt additions (at the rate of $25 \mathrm{mM} \mathrm{d}^{-1}$, starting $24 \mathrm{~h}$ after transferring the plants to the pots) were split over time in an attempt to avoid osmotic shock. All nutrient solutions were replaced every 6 days and kept aerated. Their $\mathrm{pH}$ was checked daily and adjusted to 5.5, with $0.1 \mathrm{~N} \mathrm{NaOH}$ or $0.1 \mathrm{~N} \mathrm{HCl}$, when necessary. The amount of transpired water was checked daily by weighing the pots and was replaced with distilled water. The experiment was conducted in Fortaleza $\left(3.74^{\circ} \mathrm{S}, 38.58^{\circ} \mathrm{W}\right)$, northeastern Brazil, under greenhouse conditions with mean midday photosynthetically active radiation of about $1,500 \mu \mathrm{mol} \mathrm{m} \mathrm{s}^{-2}$, temperature of $31.2 \pm 5.8^{\circ} \mathrm{C}$, and relative humidity of $72 \pm 10 \%$.

\section{Sample procedures}

On the day the plants were transferred to 3-L pots (day 0) and at 3, 10, 17, and 24 days from the start of salt additions (DSSA), leaf (third fully expanded from the apex) and root (one-third of the apical portion) segments were collected between 10:00 and 11:00 a.m., flash frozen in liquid nitrogen and then freeze-dried, as described in AzEVEDO-NETO et al. (2006). Lyophilized leaf $(20 \mathrm{mg})$ and root $(10 \mathrm{mg})$ powder were homogenized in a mortar and pestle with $1 \mathrm{~mL}$ of ice-cold extraction buffer $(100 \mathrm{mM}$ potassium phosphate, $\mathrm{pH} 7.0$, $0.1 \mathrm{mM}$ EDTA and $1 \mathrm{mM}$ ascorbate). The homogenate was filtered through muslin cloth and centrifuged (20,000 $\mathrm{g}$ for $15 \mathrm{~min})$. The supernatant fraction was used as crude extract for lipid peroxidation and enzyme activity assays. All the steps described above were carried out at about $4{ }^{\circ} \mathrm{C}$. Each replicate represented the mean of two determinations. 
Praxedes S. C., Damatta F. M., De Lacerda C. F., Prisco J. T., Gomes-Filho E.

\section{Biochemical assays}

Lipid peroxidation was determined by measuring the amount of malondialdehyde (MDA) produced by the thiobarbituric acid reaction as described by HEATH and PACKER (1968).

Total superoxide dismutase (SOD; EC 1.15.1.1) activity was determined by measuring its ability to inhibit the photochemical reduction of nitroblue tetrazolium chloride (NBT), as described by GiANNOPOLITIS and RIES (1977). The reaction mixture (1.5 mL) contained a suitable amount of extract and $50 \mathrm{mM}$ potassium phosphate, $\mathrm{pH} 7.8,0.1 \mu \mathrm{M}$ EDTA, $13 \mathrm{mM}$ methionine, $75 \mu \mathrm{M}$ NBT and $2 \mu \mathrm{M}$ riboflavin, which was the last to be added. The tubes were shaken and illuminated with two $20 \mathrm{~W}$ cool-white fluorescent lights. The reaction was allowed to proceed for $10 \mathrm{~min}$ and its absorbance was read at $560 \mathrm{~nm}$. One unit of SOD activity $(\mathrm{U})$ was defined as the amount of enzyme required to cause $50 \%$ inhibition of the NBT photoreduction rate. Other enzymes were assayed with suitable amount of extract and minor changes in the reaction media (described below): catalase (CAT; EC 1.11.1.6), $100 \mathrm{mM}$ potassium phosphate, pH 7.0, 0.1 $\mu \mathrm{M}$ EDTA, and $20 \mathrm{mM} \mathrm{H}_{2} \mathrm{O}_{2}$ (BEERS JR. and SizER 1952); ascorbate peroxidase (APX; EC 1.11.1.1), $50 \mathrm{mM}$ potassium phosphate, $\mathrm{pH}$ 6.0, $0.1 \mu \mathrm{M}$ EDTA, $0.5 \mathrm{mM}$ ascorbate, and $1.0 \mathrm{mM} \mathrm{H}_{2} \mathrm{O}_{2}$ (NAKANO and ASADA 1981); glutathione reductase (GR; EC 1.6.4.2), $100 \mathrm{mM}$ potassium phosphate, $\mathrm{pH} 7.8,0.1 \mu \mathrm{M}$ EDTA, 0.05 mM NADPH, and $3 \mathrm{mM}$ oxidized glutathione (FOYER and HALLIWELL 1976); and guaiacol peroxidase (GPX; EC 1.11.1.7), $100 \mathrm{mM}$ potassium phosphate, $\mathrm{pH} 7.0,0.1 \mu \mathrm{M}$ EDTA, 5 $\mathrm{mM}$ guaiacol, and $15 \mathrm{mM} \mathrm{H} \mathrm{O}_{2}$ (URBANEK et al. 1991). For CAT and GPX the reactions were started by adding the crude extract. APX and GR reactions were started by the addition of $\mathrm{H}_{2} \mathrm{O}_{2}$ and oxidized glutathione, respectively. All enzymatic assays were carried out at 30 ${ }^{\circ} \mathrm{C}$ and were previously checked for linearity in relation to time of reaction and amount of extract used.

\section{Experimental design and statistical analysis}

The plants were distributed over a completely randomized single-plant plot design, with four treatment combinations (two cultivars and two salt treatments) and five replicates. Differences among cultivars, salt treatments and times of collection $(0,3,10,17$ and 24 DSSA) were tested using a three-way analysis of variance. Student's $t$ test was used to compare the differences in salt treatments at the same DSSA. To examine in further detail the coupling between oxidative stress and protection, Pearson's product-moment correlation was performed using MDA pool and antioxidative enzyme activity data. Data analysis and graph generation were made using the software R (R DEVELOPMENT CORE TEAM 2012), version 2.13.1, according to SOKAL and ROHLF (1995).

\section{Results}

\section{Lipid peroxidation and antioxidant enzymes in leaves}

The salt stress treatments had similar effects on the leaf MDA concentration in both cultivars (non-significant cultivar x stress interaction), but this effect was dependent on the time of exposure to salts (significant time $\mathrm{x}$ stress and time $\mathrm{x}$ stress $\mathrm{x}$ cultivars interactions) (Tab. 1). Regardless of cultivar, significant salt-induced increases in MDA were noted par- 
Tab. 1. Three-way analysis of variance ( $F$ values) of the effect of cultivar $(\mathrm{C})$, treatment $(\mathrm{T})$ and time $(\mathrm{Tm})$ on malondialdehyde (MDA) concentration and oxidative stress enzyme activities in leaves and roots. SOD - superoxide dismutase; CAT - catalase; APX - ascorbate peroxidase; GR - gluthatione reductase; GPX - guaiacol peroxidase. Level of significance: $p=0.05(*)$, $\mathrm{p}=0.01(* *)$, n.s. - non-significant effect; $\mathrm{CV}-$ coefficient of variation.

\begin{tabular}{|c|c|c|c|c|c|c|c|c|}
\hline Traits & $\mathrm{C}$ & $\mathrm{T}$ & $\mathrm{Tm}$ & $\mathrm{CxT}$ & CxTm & TxTm & CxTxTm & $\mathrm{CV}(\%)$ \\
\hline \multicolumn{9}{|l|}{ Leaves } \\
\hline MDA & $0.01^{\text {n.s. }}$ & $47.52 * *$ & $52.36 * *$ & $0.22^{\text {n.s. }}$ & $0.78^{\text {n.s. }}$ & $6.58 * *$ & $3.53 *$ & 11.35 \\
\hline SOD & $65.83^{* *}$ & $7.75^{* *}$ & $4.97 * *$ & $0.26^{\text {n.s. }}$ & $0.94^{\text {n.s. }}$ & $6.62 * *$ & $4.09 * *$ & 18.84 \\
\hline CAT & $8.67 * *$ & $22.37 * *$ & $9.28 * *$ & $5.18 *$ & $4.32 * *$ & $1.58^{\text {n.s. }}$ & $1.74^{\text {n.s. }}$ & 35.13 \\
\hline APX & $50.63 * *$ & $43.49 * *$ & $23.56 * *$ & $12.54 * *$ & $12.78 * *$ & $15.83 * *$ & $9.12 * *$ & 30.16 \\
\hline GR & $83.06 * *$ & $1.06^{\text {n.s. }}$ & $4.73 * *$ & $1.62^{\text {n.s. }}$ & $2.40^{\text {n.s. }}$ & $12.03 * *$ & $4.47 * *$ & 29.99 \\
\hline GPX & $86.48 * *$ & $69.10 * *$ & $56.76^{* *}$ & $36.36 * *$ & $19.80 * *$ & $12.47 * *$ & $6.81 * *$ & 36.60 \\
\hline \multicolumn{9}{|l|}{ Roots } \\
\hline MDA & $16.52 * *$ & $0.05^{\text {n.s. }}$ & $11.21 * *$ & $0.90^{\text {n.s. }}$ & $3.39 * *$ & $6.77 * *$ & $1.01^{\text {n.s. }}$ & 19.23 \\
\hline SOD & $6.54 * *$ & $10.33 * *$ & $7.48 * *$ & $0.00^{\text {n.s. }}$ & $4.95 * *$ & $8.92 * *$ & $2.38^{\text {n.s. }}$ & 28.15 \\
\hline CAT & $0.01^{\text {n.s. }}$ & $1.70^{\text {n.s. }}$ & $2.04^{\text {n.s. }}$ & $0.00^{\text {n.s. }}$ & $2.03^{\text {n.s. }}$ & $3.69 *$ & $1.17^{\text {n.s. }}$ & 34.46 \\
\hline APX & $6.07 * *$ & $11.21 * *$ & $10.12 * *$ & $0.00^{\text {n.s. }}$ & $6.06 * *$ & $9.29 * *$ & $1.73^{\text {n.s. }}$ & 25.84 \\
\hline GR & $2.29^{\text {n.s. }}$ & $0.01^{\text {n.s. }}$ & $13.75 * *$ & $0.37^{\text {n.s. }}$ & $4.11 * *$ & $10.45^{* *}$ & $3.44^{*}$ & 25.54 \\
\hline GPX & $103.41 * *$ & $34.99 * *$ & $265.86 * *$ & $0.35^{\text {n.s. }}$ & $94.11 * *$ & $38.53 * *$ & $0.29^{\text {n.s. }}$ & 37.93 \\
\hline
\end{tabular}

ticularly at the end of the experiment, although such increases were found earlier in Pitiúba (at 17 DSSA) than in TVu 2331 (hereafter referred to as TVu) (Figs. 1a, b).

The salt stress also affected the antioxidant enzyme activities which was dependent on the time of exposure and cultivar (Tab. 1). On average, all the enzymes that we analyzed displayed higher activities in TVu than in Pitiúba (Tab. 1; Figs. 1, 2). In salt-stressed plants, SOD activity increased ( $<$ 0.01) at 24 DSSA in Pitiúba (Fig. 1c), but not in TVu (Fig. 1d), in which SOD did not consistently change along the experiment. In Pitiúba, CAT was not significantly affected by the treatments, whereas in TVu CAT activity was dramatically lower in salt-stressed plants as compared to their control counterparts, particularly at 10 DSSA onwards (Figs. 1e, f). With the exception of APX in Pitiúba (at 3 DSSA) and GPX in TVu (at 10 DSSA onwards), salt stress brought about significant increases in APX, GR and GPX only at the end of the experiment, though such increases were much more pronounced in TVu than in Pitiúba (Figs. 1g-1). Regardless of cultivars, both APX and GPX correlated positively $(\mathrm{p}<0.01)$ with MDA, whereas SOD was also positively correlated with MDA, but only in Pitiúba. In contrast, CAT correlated negatively with MDA $(p<0.01)$ in both cultivars (Tab. 2).

\section{Lipid peroxidation and antioxidant enzymes in roots}

Salt stress per se did not affect the MDA concentration in either cultivar, even though the MDA pools were significantly lower at 24 DSSA in salt-treated plants than in control individuals for both cultivars (significant stress $\mathrm{x}$ time and cultivar $\mathrm{x}$ time interactions) (Tab. 1; 
Praxedes S. C., Damatta F. M., De Lacerda C. F., Prisco J. T., Gomes-Filho E.

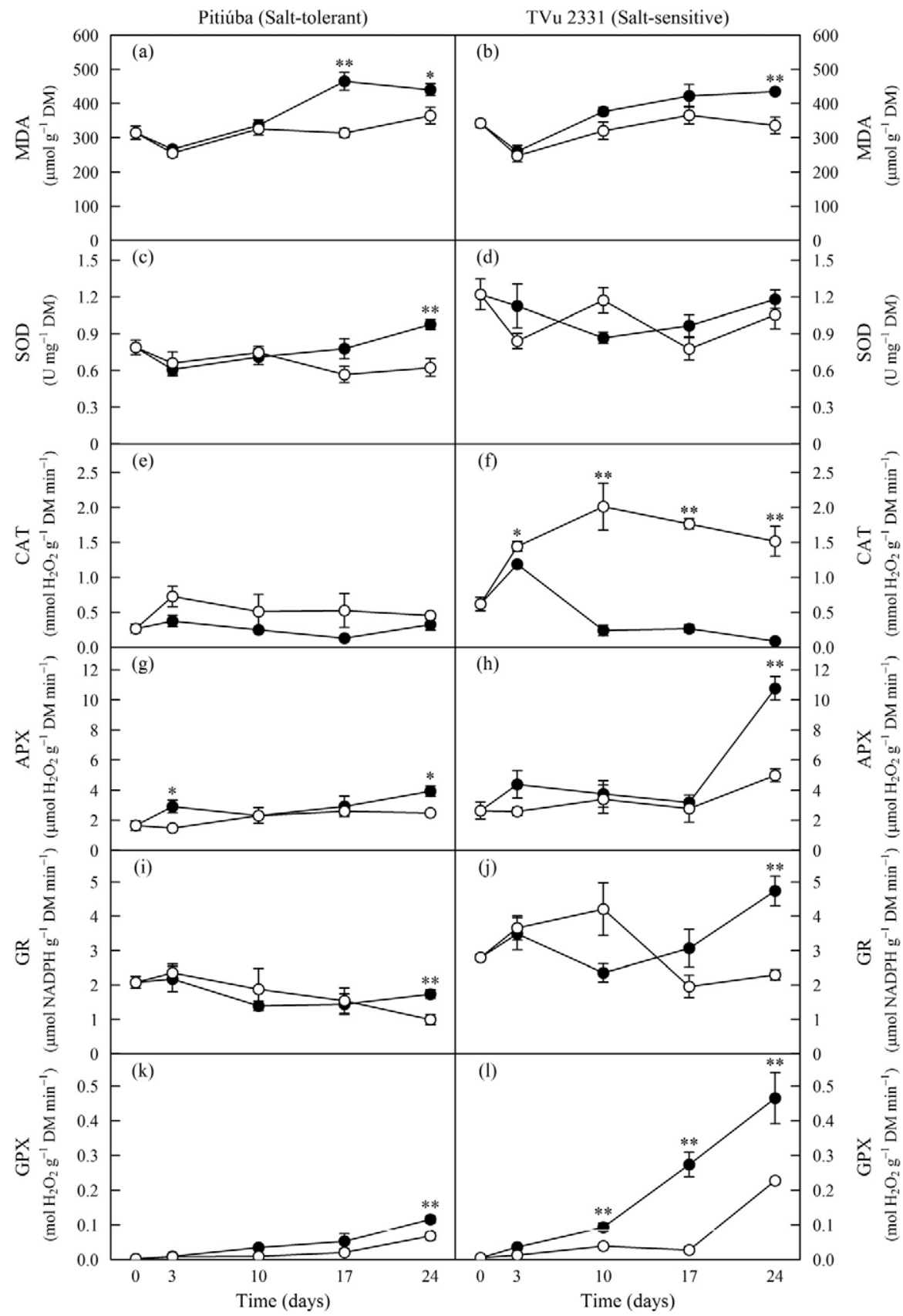

Fig. 1. Leaf concentrations of malondialdehyde (MDA; a, b), and activities of superoxide dismutase (SOD; c, d), catalase (CAT; e, f), ascorbate peroxidase (APX; g, h), gluthatione reductase $(\mathrm{GR} ; \mathrm{i}, \mathrm{j})$, guaiacol peroxidase (GPX; $\mathrm{k}, \mathrm{l})$ at different times from the start of salt additions, of two cowpea cultivars grown in nutrient solutions containing 0 (control, O) or 75 (salt stress, -) $\mathrm{mM} \mathrm{NaCl}$. Each point is the mean $\pm \mathrm{SE}$ of five replicates. Level of significance: $\mathrm{p} \leq 0.05$ $(*), \mathrm{p} \leq 0.01(* *)$ (Student's $t$ test). 
Tab. 2. Pearson's product-moment correlations between malondialdehyde (MDA) concentration and oxidative stress enzyme activities in leaves and roots. SOD - superoxide dismutase; CAT catalase; APX - ascorbate peroxidase; GR - gluthatione reductase; GPX - guaiacol peroxidase. Level of significance: $\mathrm{p}<0.05(*), \mathrm{p}<0.01(* *)$, n.s. - non-significant effect.

\begin{tabular}{|c|c|c|c|c|}
\hline & \multicolumn{2}{|c|}{ Pitiúba } & \multicolumn{2}{|c|}{$\mathrm{TVu}$} \\
\hline & Leaves & Roots & Leaves & Roots \\
\hline SOD & $0.52 * *$ & $-0.18^{\text {n.s. }}$ & $0.13^{\text {n.s. }}$ & $0.09^{\text {n.s. }}$ \\
\hline CAT & $-0.37 *$ & $0.09^{\text {n.s. }}$ & $-0.53 * *$ & $-0.15^{\text {n.s. }}$ \\
\hline APX & $0.42 * *$ & $0.16^{\text {n.s. }}$ & $0.40^{* *}$ & $0.02^{\text {n.s. }}$ \\
\hline GR & $-0.29^{\text {n.s. }}$ & $0.07^{\text {n.s. }}$ & $0,10^{\text {n.s. }}$ & $-0.39^{\text {n.s. }}$ \\
\hline GPX & $0.72 * *$ & $0.08^{\text {n.s. }}$ & $0.67 * *$ & $0.02^{\text {n.s. }}$ \\
\hline
\end{tabular}

Figs. 2a, b). On average, the MDA concentration was significantly lower in TVu than in Pitiúba.

Regardless of the salt treatments, the average activities of SOD, APX and GPX were slightly larger in TVu than in Pitiúba, with no cultivar difference found for CAT and GR activities (Tab. 1, Fig. 2). In general, salt-induced increases in enzyme activities were particularly noted at 24 DSSA, as found for SOD and APX in Pitiúba, CAT in TVu and GR and GPX in both cultivars (significant cultivar $\mathrm{x}$ time (except for CAT) and stress $\mathrm{x}$ time interactions) (Tab. 1, Figs. 2c-1). Notably, the activities of some antioxidative enzymes, especially SOD and APX, were remarkably larger in roots than in leaves regardless of cultivar and salt treatment ( $c f$. Figs. 1, 2). Irrespective of cultivar, no significant correlation was found between antioxidant enzymes and MDA pools (Tab. 2).

\section{Discussion}

The effects of oxidative stress on membranes are frequently evaluated through the increases in MDA concentration, a byproduct of lipid peroxidation (BoR et al. 2003, PINHEIRO et al. 2004, SÁNCHEZ-RODRÍGUEZ et al. 2010). Therefore, increases in MDA levels have commonly been reported along with the exposition time to salts (BOR et al. 2003, BANU et al. 2009). Here, we noted that the MDA pools increased earlier in the leaves of the salt-tolerant Pitiúba than in the salt-sensitive TVu, suggesting increased oxidative stress in that cultivar which could correlatively be associated with a less robust enzymatic antioxidant system in Pitiúba than in TVu. On the other hand, the elevated antioxidant enzyme activities in TVu could be interpreted as an intrinsic higher tolerance to oxidative stress (overall, higher enzyme activities in both leaves and roots regardless of salt treatments). An upregulation of some antioxidant enzymes (particularly APX, GR and GPX) under salt stress conditions could also play an important role in efficiently scavenging ROS that are expected to be produced at higher rates in TVu than in Pitiúba due to larger decreases in both growth and photosynthetic rates and higher $\mathrm{Na}^{+}$accumulation in the former (PRAXEDES et al. 2010) so that MDA accumulation could be held in check.

The ratio between the activity of SOD and the activities of APX and CAT has a pivotal role in controlling the cellular levels of the superoxide radical and hydrogen peroxide (MitTLER 2002). APX has higher affinity by hydrogen peroxide than CAT, thus APX should 
Praxedes S. C., Damatta F. M., De Lacerda C. F., Prisco J. T., Gomes-Filho E.

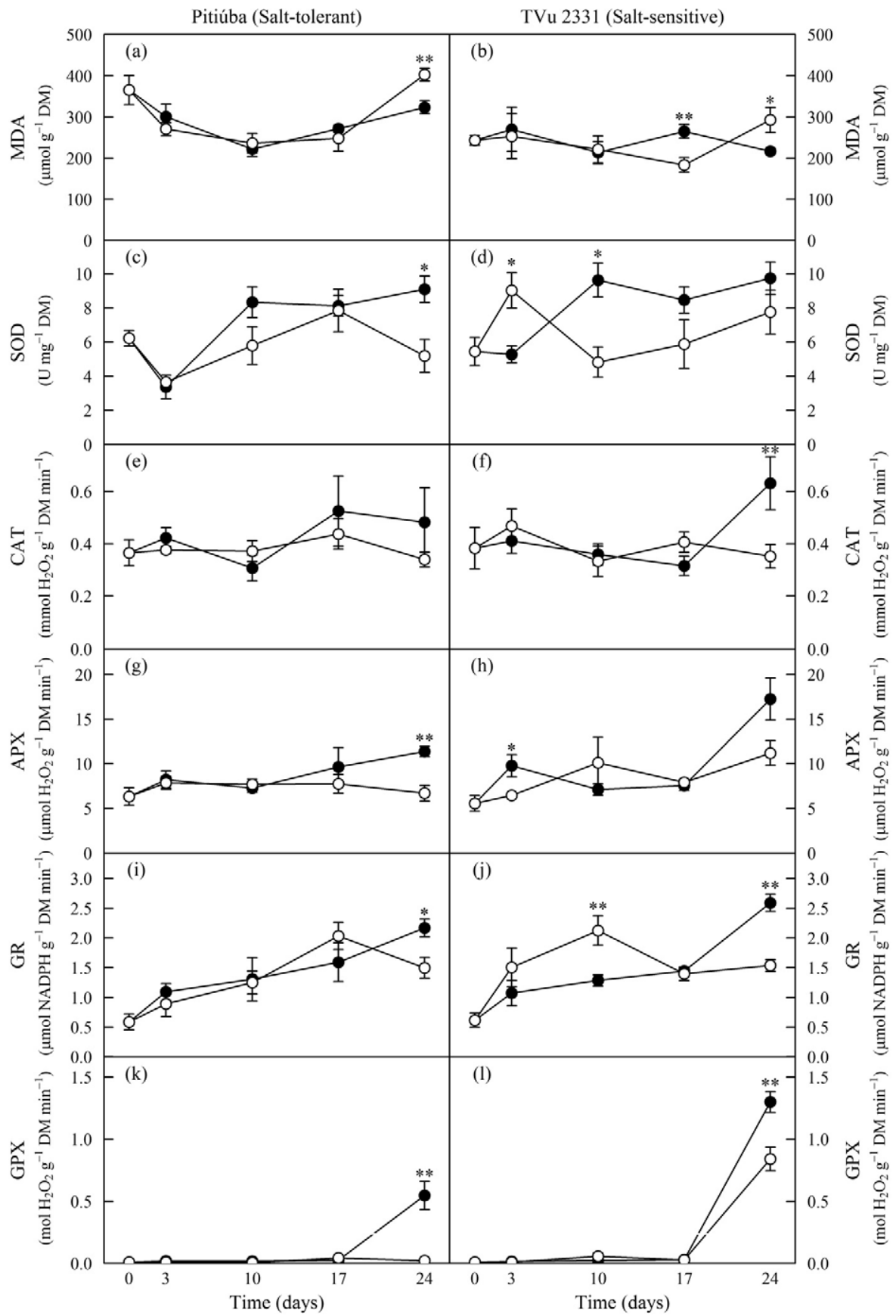

Fig. 2. Root concentrations of malondialdehyde (MDA; a, b), and activities of superoxide dismutase (SOD; c, d), catalase (CAT; e, f), ascorbate peroxidase (APX; g, h), gluthatione reductase $(\mathrm{GR} ; \mathrm{i}, \mathrm{j})$, guaiacol peroxidase (GPX; $\mathrm{k}, \mathrm{l})$ at different times from the start of salt additions, of two cowpea cultivars grown in nutrient solutions containing 0 (control, $\mathrm{O}$ ) or $75(\bullet) \mathrm{mM}$ $\mathrm{NaCl}$. See further details in legend to figure 1. 
be involved primarily in fine signal modulation against ROS, while CAT would be involved in the removal of ROS excess during oxidative stress (MITTLER 2002). Here, we found that whereas SOD and APX activities were either stimulated or unchanged in response to salt stress in the leaves of both cultivars, CAT activity dramatically decreased under salt-stress conditions, as noted in TVu. Some studies have previously reported inhibition in CAT activity in leaves of cowpea seedlings challenged with salt stress growing under soil conditions (CAVAlCANTI et al. 2007, MAiA et al. 2010). CAVALCANTI et al. (2007) suggested that such inhibition was associated with irreversible damages suffered by the enzyme, which is markedly sensitive to salt excess (HERTWIG et al. 1992). Therefore, we contend that damage in CAT might have occurred here in TVu, which accumulated salts in leaves to a greater extent than Pitiúba (PRAXEDES et al. 2010). This might lend some support to explain the stronger negative correlation between CAT and MDA in TVu than in Pitiúba. In any case, the significance of particular activities of ROS scavenging enzymes should be interpreted based on the overall plant response to salt stress, the cellular levels of ROS and the activities of other enzymes involved in ROS scavenging in order to make a precise correlation between enzyme activity and plant acclimation to salt stress (ABOGADALLAH 2010). In this regard, higher activities of APX, GR and GPX could compensate for the decreased CAT activity in salt-treated TVu plants in order to restrain the development of oxidative damage. This is circumstantially supported by the correlation analysis between the antioxidant enzymes and MDA concentrations in both cultivars, that is, the greater the oxidative pressure (higher MDA), the greater the activities of SOD, APX and GPX and SOD.

In contrast with leaves, the levels of MDA in roots ultimately decreased at the end of the experiment in salt-treated plants from both cultivars as compared with untreated individuals, which was accompanied by increased activities of some antioxidant enzymes. Notably, the MDA concentration tended to be lower in roots than in leaves in both cultivars, which could be related to the higher activities of some enzymes such as SOD and APX in roots than in leaves.

Overall, our results contrast with those reported by MAIA et al. (2010). These authors found positive correlations between leaf SOD, APX or GPX activities with salt stress tolerance, but these results were obtained using another cowpea genotype as a salt-sensitive cultivar with different age and grown under conditions different from those used in this current study. Although we have highlighted the importance of antioxidant enzymes in cowpea acclimation to salt stress, no positive correlation between increases in the activities of enzymes and salt stress tolerance was found in this current long-term study. Therefore, the enzymatic protection mechanism against salt stress might be a good selection marker for some species or genotypes but not for others, as had already been shown by ABOGADALLAH (2010).

\section{Conclusions}

Despite some changes found in the expression of the enzymatic antioxidant system, particularly in leaves, the present results argue against our working hypothesis that the salt-sensitive cultivar is more prone to suffer from oxidative stress. However, the nonenzymatic system was not evaluated and accordingly merits attention in future studies. We also demonstrated that leaves and roots displayed varying antioxidant abilities to cope with salt stress and so 
Praxedes S. C., Damatta F. M., De Lacerda C. F., Prisco J. T., Gomes-Filho E.

both types of organs should be evaluated for a full assessment of whole-plant acclimation to salt stress.

\section{Acknowledgement}

The authors would like to thank the Conselho Nacional de Desenvolvimento Científico e Tecnológico (CNPq) for their financial support and the Coordenação de Aperfeiçoamento de Pessoal de Nível Superior (CAPES) for a PhD scholarship to S. C. Praxedes.

\section{References}

Abogadallah, G. M., 2010: Antioxidative defense under salt stress. Plant Signaling and Behavior 5, 369-374.

Ahmad, P., Sarwat, M., Sharma, S., 2008: Reactive oxygen species, antioxidants and signaling in plants. Journal of Plant Biology 51, 167-173.

AsADA, K., 1999: The water-water cycle in chloroplasts: scavenging of active oxygens and dissipation of excess photons. Annual Review of Plant Physiology and Plant Molecular Biology 50, 601-639.

Azevedo-Neto, A. D., Prisco, J. T., Enéas-Filho, J., Abreu, C. E. B., Gomes-Filho, E., 2006: Effect of salt stress on antioxidative enzymes and lipid peroxidation in leaves and roots of salt-tolerant and salt-sensitive maize genotypes. Environmental and Experimental Botany 56, 87-64.

Banu, M. N. A., Hoque, M. A., Watanabe-Sugimoto, M., Matsuoka, K., NaKamura, Y., SHIMOISHI, Y., MurAtA, Y., 2009: Proline and glycinebetaine induce antioxidant defense gene expression and suppress cell death in cultured tobacco cells under salt stress. Journal of Plant Physiology 166, 146-156.

BEERS-JR, R. F., SizER, I. W., 1952: A spectrophotometric method for measuring the breakdown of hydrogen peroxide by catalase. Journal of Biological Chemistry 195, 133-140.

Bor, M., ÖZDEMIR, F., TürKAN, I., 2003: The effect of salt stress on lipid peroxidation and antioxidants in leaves of sugar beet Beta vulgaris L. and wild beet Beta maritima L. Plant Science 164, 77-84.

Cavalcanti, F. R., Lima, J. P. M. S., Silva, S. L. F., Viégas, R. A., Silveira, J. A. G., 2007: Roots and leaves display contrasting oxidative response during salt stress and recovery in cowpea. Journal of Plant Physiology 164, 591-600.

Costa, P. H. A., Silva, J. V., Bezerra, M. A., EnÉAs-Filho, J., Prisco, J. T., Gomes-Filho, E., 2003: Crescimento e níveis de solutos orgânicos e inorgânicos em cultivares de Vigna unguiculata submetidos à salinidade. Revista Brasileira de Botânica 26, 289-297.

Ehlers, J. D., HAll, A. E., 1997: Cowpea (Vigna unguiculata L. Walp.). Field Crops Research 53, 187-204.

Foyer, C. H., HALliwell, B., 1976: The presence of glutathione and glutathione reductase in chloroplasts: a proposed role in ascorbic acid metabolism. Planta 133, 21-25.

Giannopolitis, C. N., Ries, S. K., 1977: Superoxide dismutases. I. Occurrence in higher plants. Plant Physiology 59, 309-314. 
Hasegawa, P. M., Bressan, R. A., Zhu, J. K., Bohnert, H. J., 2000: Plant cellular and molecular responses to high salinity. Annual Review of Plant Physiology and Plant Molecular Biology 51, 463-499.

HeAth, R. L., PACKeR, L., 1968: Photoperoxidation in isolated chloroplasts. I. Kinetics and stochiometry of fatty acid peroxidation. Archives of Biochemistry and Biophysics 125, 189-198.

Hertwig, B., Streb, P., Feierabend, J., 1992: Light dependence of catalase synthesis and degradation in leaves and the influence of interfering stress conditions. Plant Physiology 100, 1547-1553.

Maia, J. M., Macedo, C. E. C., Voigt, E. L., Freitas, J. B. S., Silveira, J. A. G., 2010: Antioxidative enzymatic protection in leaves of two contrasting cowpea cultivars under salinity. Biologia Plantarum 54, 159-163.

MitTLER, R., 2002: Oxidative stress, antioxidants and stress tolerance. Trends in Plant Science 7, 405-410.

Munns, R., Tester, M., 2008: Mechanisms of salinity tolerance. Annual Review of Plant Biology 59, 651-681.

NAKANO, Y., AsADA, K., 1981: Hydrogen peroxide is scavenged by ascorbate-specific peroxidases in spinach chloroplasts. Plant Cell Physiology 22, 867-880.

Palatnik, J. F., Valle, E. M., Federico, M. L., Gómez, L. D., Melchiorre, M. N., Paleo, A. D., CARrillo, N., Acevedo, A., 2002: Status of antioxidant metabolites and enzymes in a catalase-deficient mutant of barley (Hordeum vulgare L.). Plant Science 162, 363-371.

PARIDA, A. K., DAS, A. B., 2005: Salt tolerance and salinity effects on plants: a review. Ecotoxicology and Environmental Safety 60, 324-349.

Pinheiro, H. A., Damatta, F. M., Chaves, A. R. M., Fontes, E. P. B., Loureiro, M. E., 2004: Drought tolerance in relation to protection against oxidative stress in clones of Coffea canephora subjected to long-term drought. Plant Science 167, 1307-1314.

Praxedes, S. C., Lacerda, C. F., Damatta, F. M., Prisco, J. T., Gomes-Filho, E., 2010: Salt tolerance is associated with differences in ion accumulation, biomass allocation and photosynthesis in cowpea cultivars. Journal of Agronomy and Crop Science 196, 193-204.

R Development Core Team, 2012: R: A Language and Environment for Statistical Computing. R Foundation for Statistical Computing, Vienna. Retrieved April 18, 2012 from http://www.R-project.org

SÁnchez-Rodríguez, E., Rubio-Wilhelmi, M. M., Cervilla, L. M., Blasco, B., Rios, J. J., Rosales, M. A., Romero, L., RuIZ, J. M., 2010: Genotypic differences in some physiological parameters symptomatic for oxidative stress under moderate drought in tomato plants. Plant Science 178, 30-40.

SoKal, R. R., RoHLF, F. J., 1995: Biometry: The principles and practice of statistics in biological research. W. Freeman and Company, New York, USA.

Timko, M. P., Rushton, P. J., Laudeman, T. W., Bokowiec, M. T., Chipumuro, E., Cheung, F., Town, C. D., CHEn, X., 2008: Sequencing and analysis of the gene-rich space of cowpea. BMC Genomics 9, 103-123. 
Praxedes S. C., Damatta F. M., De Lacerda C. F., Prisco J. T., Gomes-Filho E.

Urbanek, H., KuZniak-Gebarowska, E., Herka, K., 1991: Elicitation of defense responses in bean leaves by Botrytis cinerea polygalacturonase. Acta Physiologiae Plantarum 13, 43-50.

Zhang, J., Kirkham, M. B., 1996: Antioxidant responses to drought in sunflower and sorghum seedlings. New Phytologist 132, 361-373. 